\title{
Tympanometric Evaluation in Cerebral Palsy Patients in Benin City Nigeria
}

\author{
Akpalaba I. O. ${ }^{1}$, Ogisi F.O. ${ }^{2}$ \\ Department of Ear, Nose and Throat, University of Benin Teaching Hospital, (UBTH), Benin City, Edo State
}

\begin{abstract}
Cerebral palsy is a static neurologic condition from brain injury that occurred before cerebral development is complete. ${ }^{1}$ Such patients are vulnerable to hearing loss. ${ }^{23,}{ }^{24}$ This hearing loss can be due to middle ear pathology, which is preventable and correctable. The aim was to determine the pattern of middle ear pathology and severity of Eustachian Tube Dysfunction (ETD) in Cerebral Palsy patients at UBTH. This was a prospective descriptive study carried out for fourteen months (May 2014 to June 2015). Total population sampling technique was used. 112 subjects participated, each ear, as a separate entity. Pretest was done on 60 subjects at Project Chari-love. Structured interviewer questionnaire was administered, otoscopy and Tympanometry were done. Data analyzed using Statistical Package for Scientific Solution version 16. Similar procedures were carried out on 112 control subjects comprising children in Russell International Group of Schools, Ugbowo, Benin city. Otitis Media with Effusion predominated in 154 (68.8\%) ears compared to $25.9 \%$ in the control. ETD, 129 (57.6\%), mostly Type C1. Reduced middle ear compliance noted in 22 (9.9\%) ears. ( p $<0.001)$. Middle ear pathology is predominant in cerebral palsy patients. Otitis Media with Effusion is the commonest. ETD was mostly Type C1.
\end{abstract}

Keywords: Middle ear, Cerebral Palsy, Tympanometry, Otitis media, Effusion

\section{Introduction}

Cerebral palsy is a static neurologic condition from brain injury that occurred before cerebral development is complete. ${ }^{1}$ Because brain development continues during the first two years of life, cerebral palsy can result from brain injury occurring during the prenatal, perinatal, or postnatal periods. ${ }^{1}$ Seventy to 80 percent of cerebral palsy cases are acquired prenatally and from largely unknown causes. ${ }^{1}$

Pre and post natal risk factors for cerebral palsy are birth lesser than 32 weeks' gestation, birth weight of less than 2,500g, intrauterine growth retardation, intracranial hemorrhage, trauma as well as birth asphyxia. ${ }^{1}$ Others are brain damage from bacterial meningitis, viral encephalitis, hyperbilirubinemia, motor vehicle collisions, falls, or child abuse. ${ }^{1}$

The diagnosis is made from observation of slow motor development, abnormal muscle tone, and unusual posture. ${ }^{1}$ Assessment of persistent infantile reflexes is important. In infants who do not have cerebral palsy, the Moro reflex is rarely present after six months of age, and hand preference rarely develops earlier than 12 months of age. Hand preference may occur before 12 months of age if spastic hemiplegia is present. ${ }^{1}$ Targeted laboratory tests and cerebral imaging using computed tomography scan, magnetic resonance imaging, and ultrasound are useful physical diagnostic tools. ${ }^{1}$ It is the most common childhood developmental disability. ${ }^{1,2}$

\subsection{Literature Survey}

Earlier studies showed that it affects 2.5 to 10.3 children per 1,000 live births in Nigeria. ${ }^{3,4,5}$ In the industrialized World, the incidence of cerebral palsy is about 2 per 1000 live birth. $^{6}$
Cerebral palsy is characterized by motor impairment and can present with global physical and mental dysfunction. ${ }^{1}$ Although impaired motor function is the hallmark of the cerebral palsy (CP) syndromes, many children with this developmental disorder also experience sensory, communicative and intellectual impairments and may have complex limitations in self-care functions. ${ }^{1}$ Some of the medical disorders associated with cerebral palsy include mental impairment, epilepsy, growth problems, vision impairment, hearing impairment and intellectual impairment. $^{7}$

Impaired hearing occurs more frequently among those with cerebral palsy than in the general population. ${ }^{7}$ Recent studies have shown that up to 15 percent of children with cerebral palsy also have some kind of hearing impairment. ${ }^{7}$ Hearing loss in cerebral palsy can be due to middle ear pathologies, which is both preventable and correctable. This justifies the study.

\subsection{Research Questions}

1) Is middle ear pathology common in children with Cerebral palsy in University of Benin Teaching Hospital?

2) How severe is Eustachian tube dysfunction in children with Cerebral palsy in University of Benin Teaching Hospital?

\subsection{Null Hypotheses $\left(\mathrm{H}_{0}\right)$}

1) There is no significant relationship between the prevalence of middle ear pathology and the severity of cerebral palsy (degree of disability) in University of Benin Teaching Hospital. $\left(\mathrm{H}_{01}\right)$

2) There is no significant relationship between the severity of Eustachian tube dysfunction and the severity of cerebral palsy (degree of disability) in University of Benin Teaching Hospital. $\left(\mathrm{H}_{02}\right)$ 


\section{International Journal of Science and Research (IJSR) \\ ISSN (Online): 2319-7064 \\ Index Copernicus Value (2013): 6.14 | Impact Factor (2014): 5.611}

\subsection{Alternate Hypotheses}

1) There is a significant relationship between the prevalence of middle ear pathology and the severity of cerebral palsy (degree of disability) in University of Benin Teaching Hospital.

2) There is a significant relationship between the severity of Eustachian tube dysfunction and the severity of cerebral palsy (degree of disability) in University of Benin Teaching Hospital.

Tympanometry is an objective measurement of the middle ear function which provides useful quantitative information about the presence of fluid in the middle ear, mobility of the middle ear system, and ear canal volume. ${ }^{8}$ Its use has been recommended in conjunction with more qualitative information (e.g., history taking, appearance, and mobility of the tympanic membrane) in the evaluation of otitis media with effusion and to a lesser extent in acute otitis media. ${ }^{8}$ It can also provide useful information about the patency of tympanostomy tubes. ${ }^{8}$ Tympanogram tracings are classified as type A (normal), with subtypes As and Ad, type B (flat, clearly abnormal), and type C (indicating a significantly negative pressure in the middle ear, possibly indicative of pathology). ${ }^{8}$
Type A

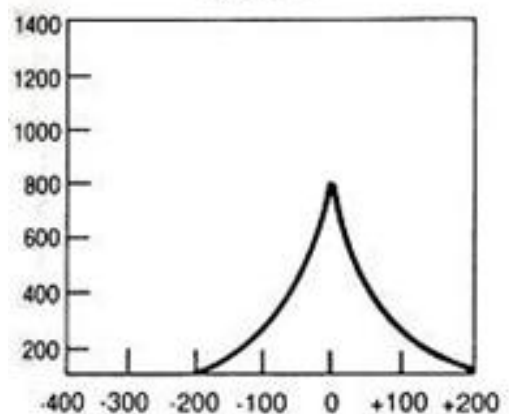

Type B

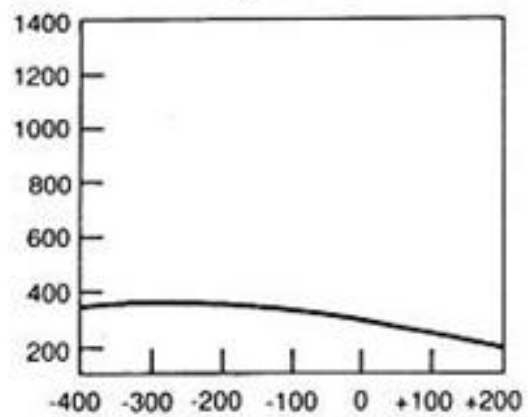

\section{Type C}

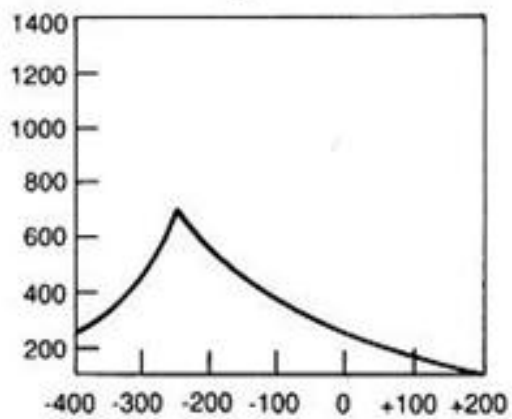

Type As

\section{Type AD}

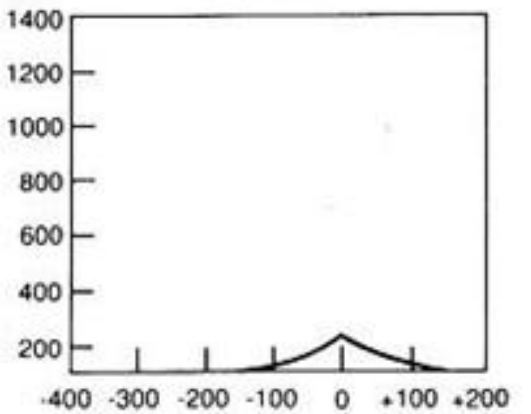

Figure 1: Tympanogram tracings ${ }^{9}$

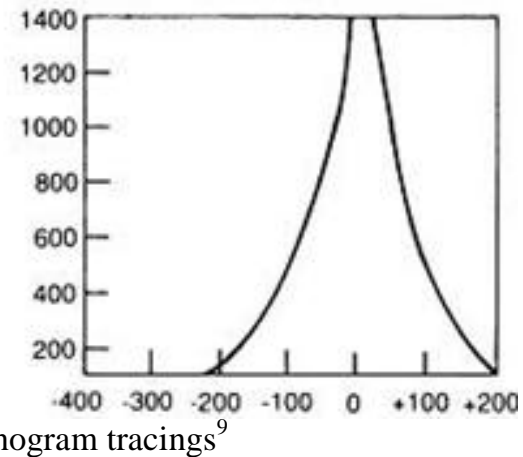

In a study conducted to detect early changes in audiologic function in children with cerebral palsy in Al-Hussein University Hospitals and the Research Institute of Ophthalmology, Egypt in 2010, abnormal tympanometry in the form of secretory otitis media and eustachian tube dysfunction was recorded in 52\% of the spastic quadriplegic type. ${ }^{10}$ Other remaining types had normal tympanometry. Other researchers in Germany reported that $15 \%$ respondent of 61 children with cerebral palsy had middle ear pressure below $-50 \mathrm{mmH}_{2} \mathrm{O}$ while $75 \%$ were above $50 \mathrm{mmH}_{2} \mathrm{O}{ }^{11}$

\section{Aim and Objectives \\ This study was conducted to determine the pattern of middle ear pathology in children with Cerebral Palsy at University of Benin Teaching Hospital and to assess the severity of their Eustachian Tube Dysfunction.}

\section{Scope of the Study}

This study focused on cerebral palsy patients attending occupational therapy at University of Benin Teaching Hospital, assessment of their middle ear pathology through structured interviewer questionnaire, Otoscopy and tympanometry.

\section{Patients and Methods}

This was a prospective descriptive study carried out for fourteen months from May 2014 to June 2015 at the University of Benin Teaching Hospital, (UBTH), Benin City, Edo state, Nigeria. University of Benin Teaching Hospital, UBTH, is a tertiary health institution which serves Edo state as well as other neighboring geographical states of Nigeria, with many referrals from these states. It is situated along Benin - Lagos express road in Egor Local Government Area of Edo state. The Hospital has 24 wards of 30 beds each. There are many departments including ENT Head and Neck Surgery department, which provide both out and in care specialist services. The study was conducted in the Occupational Therapy department (OTD) of the hospital. This department is responsible for rehabilitation and restoration of body function in patients with motor and intellectual disorders. There are seven occupational therapists and variable number of interns in the department with adequate adult and pediatric facilities. They receive referrals from Child Health department, Neurosurgery, E.N.T, General Practice clinic and Psychiatry. Consequently the department attends to patients with Cerebral palsy, Autism, Attention Deficit Syndrome, hyperactive syndrome, adult with varying degrees of neurological and motor deficit 


\section{International Journal of Science and Research (IJSR) \\ ISSN (Online): 2319-7064}

Index Copernicus Value (2013): 6.14 | Impact Factor (2014): 5.611

amongst other neurological disabilities. They receive an average of 10 patients (old and new) per day in a 5 working days. They recorded 235 cerebral palsy patients in the last 2years.

The control study was done at Russell International group of schools, Ugbowo Benin city, Nigeria.

\section{Study Population}

All children with Cerebral palsy who attended Occupational therapy sessions in UBTH during the period of study were subjects for the study. The control was all recruited children attending Russell International group of schools, Ugbowo Benin city, whose parents gave consent.

\section{Inclusion Criteria}

Children with Cerebral palsy whose parents or caregivers gave consent were involved in the study. The diagnosis of Cerebral palsy was made based on delayed milestone in patients with previous history of jaundice, fall from height or trauma with resultant head injury or those who had regression of already attained milestone following a systemic illness which occurred before the age of 2 years.

\section{Exclusion Criteria}

Patients with cerebral palsy whose parents or caregivers did not give consent to the study were excluded.

\section{Control Group}

School children attending Russell International Group of schools Ugbowo, Benin city, from pre- KG class to senior secondary 3 class, within the age range 1 - 18years whose parents gave consent to the study.

\section{Sample Size Determination:}

The minimum sample size for this study was calculated using the Cochran's formula ${ }^{12,13}$

$$
n=\frac{Z^{2} p q}{d^{2}}
$$

Where $\mathrm{n}$ is minimum sample size required for the study $\mathrm{p}=$ Proportion of Children with Cerebral palsy in a population based study done in Port Harcourt, Nigeria and Victoria, Australia ${ }^{4,14} \mathrm{p}=6 \%$

$=0.06$

$\mathrm{q}=1-\mathrm{p}$

$=1-0.06=0.94$

$\mathrm{d}=$ Error margin (Precision) desired. Usually set at 5\% = 0.05

$\mathrm{Z}=$ Standard normal deviation. Usually set at 95 percent confidence level. $(Z=1.96)$

Applying the formula: $\mathrm{n}=(1.96)^{2} \times 0.06 \times 0.94 /(0.05)^{2}$

$\mathrm{n}=0.21667 / 0.0025$

$\mathrm{n}=86.6$ i.e. approximately $\mathrm{n}=87$

Attrition rate at $10 \%$ of $n=8.7$

Therefore $87+8.7=95.7$, approximately 96

By correcting for attrition at a rate of $10 \%$, a minimum of 96 respondents was determined.

The minimum sample size for this study was approximated to 100 .

\section{Sampling Technique}

A total population study technique was used for the cases.

Step 1: All the cerebral palsy patients that came for occupational therapy on the first day of study who consented were selected.

Step 2: Subsequently, all (new or old patients) who had not been previously assessed, were consecutively recruited until the sample size was achieved.

Stratified sampling technique was used to recruit the control group based on age and sex categorization from the selected school until the control group sample size was achieved

Pre Testing: The data collection instruments were pre-tested among children in Project Charilove, which is a Nongovernmental organization for children with disability and delayed developmental milestones. This center is located in Oredo Local Government, Area, Edo State, which is about $10 \mathrm{~km}$ away from UBTH.

\section{Ethical Considerations}

Ethical clearance was obtained from the Research and Ethics Committee, UBTH, Benin City. Individual informed and written consent form was obtained and attached to each questionnaire and the care giver gave his or her consent on behalf of the respondent before the questionnaire was filled.

Approval was also obtained from the Head of Department of Occupational Therapy, University of Benin Teaching Hospital, Benin City and the school authority of Russell International group of schools, Ugbowo, Benin city.

Participation was purely voluntary and there was no inducement or undue influence on participants.

Adequate professional steps were taken to ensure the protection of the right and dignity of each subject according to the provisions of the second declaration of Helsinki on research involving human beings. ${ }^{15}$

Data were collected using quantitative methods. Data collection instrument is as shown below. Four Research Assistants were recruited and trained within a period of two days on how to administer and fill the questionnaires properly. The Research Assistants were; a fellow resident in the E.N.T department, two audiology technicians and an occupational therapist.

\section{Tools of Data Collection}

\section{Questionaire}

Structured, interviewer administered questionnaire was administered to the children and care-givers; it consisted of the following sections:

For the cases:

Section A: Socio-Demographic data of Parents/ Caregivers

Section B: Socio-Demographic data of patient Section C: Questions on Possible pattern of any middle ear pathology present in the patient with Cerebral Palsy Section D: Questions on possible Eustachian Tube pathology in the patient with Cerebral Palsy 


\section{International Journal of Science and Research (IJSR) \\ ISSN (Online): 2319-7064 \\ Index Copernicus Value (2013): 6.14 | Impact Factor (2014): 5.611}

For the control:

Section A: Socio-Demographic data of Parents/ Guardian

Section B: Socio-Demographic data of child

Section C: Questions on Possible pattern of any middle

ear pathology

Section D: Questions on possible Eustachian Tube

pathology

Materials Needed for the Study

1) Head light used for examination of the Ear, Nose and Throat

2) Hand held battery powered Otoscope (R.A. Bock Diagnostics) - for aural examination (with appropriate sized re-usable speculum)

3) 3.Tympanometer, Welch-Allyn Autotymp (see Appendix 111), (TM 262), version 4, 2008, (Type BFIEC 6060 II/EN 6060 I-I) with the following specifications, Probe Tone frequency of $226 \mathrm{HZ}$, Sound Pressure level of $85 \mathrm{~dB}$ with Pressure range of +200 to $-400 \mathrm{daPa}$.

4) Questionnaire (Appendix 1 and 11)

\section{Method}

The study was undertaken after ethical approval was obtained from the UBTH Research Ethical committee and a written informed consent duly signed. The Subjects who were selected had full E.N.T. history taken which helped to ascertain the risk factor for middle ear pathology. A talk on the aim and objectives of the study and possible interventions was given to the parents and caregivers. The interviewer administered questionnaires were then completed by the researchers and their trained assistants. The Questionnaires covered information on SocioDemographic data of Parents/Guardian. Socio-Demographic data of patient and possible middle ear including Eustachian tube pathology. The interview to complete the questionnaire was done in the language the respondent understood very well. Interpreters were used where need be for easy communication.

Thereafter, complete general/physical examination with particular emphasis on Ear, Nose, Throat, Head and Neck was done. Patient's ears were examined for structural anomalies, with the aid of head light and Otoscope. Ear canal was examined for the presence of wax, ear discharge, foreign objects, tympanic membrane perforation, its nature and any other sign of external or middle ear pathologies. For the purpose of this study, each ear was regarded as a separate entity during examination. Speculum used for each patient during otoscopy, was thoroughly disinfected before re-use on another patient. Wax and foreign body found during otoscopy were removed before tympanometric evaluation was done.

Tympanometry was performed on each ear, using a WelchAllyn Autotymp (TM 262), Version 4, 2008. A Type BFIEC 6060 I-I/EN 6060 I-I Tympanometer pre-calibrated to ISO standard, with the following specifications: Probe Tone frequency of 226HZ, Sound Pressure level of $85 \mathrm{~dB}$ SPL with pressure range of +200 to $-400 \mathrm{daPa}$. Prior to the test, optimum effort was made to caution the patient not to swallow, yawn, talk or blink the eyes to avoid pressure changes and motility of the tympanic membrane during the test. Appropriate sized probe-tip of the tympanometer was used to seal each of the EAC before the tympanometer was started. The Tympanograms were automatically printed out after each measurement. Fiellau Nikolajsen (1983) and modified Jerger's (1970) nomenclature, which subdivide Tympanograms into four types were used. ${ }^{16}$

Type A (and subtypes As, Ad) - Middle ear pressure + 200 to $-99 \mathrm{~mm}$ of Water.

Type B - Flat traces without a well defined compliance.

Type C1- Middle ear pressure - 100 to $-199 \mathrm{~mm}$ of Water.

Type C2- Middle ear pressure - 200 to - $400 \mathrm{~mm}$ of Water

Types C1 and C2 associated with a negative middle ear pressure as in Eustachian tube dysfunction, also associated with middle ear effusion and the type B flat curve, which is highly associated with middle ear effusion, were used as indicators of Otitis Media with Effusion.

Each probe was thoroughly disinfected prior to re-use. Each of the Tympanograms were analyzed. Subjects that had middle ear pathology were referred to Ear Nose and Throat Department, UBTH, for further evaluation and management. Similar procedures were carried out among controls matched $1: 1$ for age and gender.

\section{Limitations of Methodology}

Some of the patients were unable to obey instructions.

Some parents were uncomfortable answering questions concerning their child, because of associated social stigma.

The responses were self reported by the patients and caregivers, and the extent of underreporting or over reporting of variables could not be determined.

Similar studies on cerebral palsy were scarce.

These patients could have benefitted from Pure Tone Audiometry to ascertain the degree of their hearing loss but was not done due to their inability to cooperate.

Brainstem Evoked Response Audiometry (BERA) would have correctly ascertained the hearing status of these patients involved.

\section{Pneumatic otoscopy was not done.}

Collected quantitative data were entered and analyzed using Statistical Package for Scientific Solution, (SPSS) version 16. Descriptive and inferential analysis was carried out in line with the objectives of the study. Statistical test of association was carried out using a 95 percent confidence interval. P value less than 0.05 was considered statistically significant.

\section{Results}

\section{Socio-Demographic Characteristics}

224 respondents participated in the study. Age ranged from 1 - 18 years with a mean age of $9.69 \pm 6.53$ years. One hundred and twenty cerebral palsy patients were screened 


\section{International Journal of Science and Research (IJSR) \\ ISSN (Online): 2319-7064 \\ Index Copernicus Value (2013): 6.14 | Impact Factor (2014): 5.611}

during the period of data collection. Three were less than syringing for wax impaction failed to complete the study. one year old and were disqualified. Five cases who had ear

Table 1: Socio-Demographic Characteristics of Patients

\begin{tabular}{|c|c|c|c|c|c|}
\hline \multirow{2}{*}{ Variable } & \multicolumn{3}{|c|}{ Class } & \multirow{2}{*}{ Test statistic } & \multirow{2}{*}{ p value } \\
\cline { 2 - 4 } & $\begin{array}{c}\text { Case } \\
\text { N (\%) }\end{array}$ & $\begin{array}{c}\text { Control } \\
\text { N (\%) }\end{array}$ & $\begin{array}{c}\text { Total } \\
\text { N (\%) }\end{array}$ & & \\
\hline Age (years) & & & & & \\
\hline $1-5$ & $37(33.0)$ & $48(42.9)$ & $85(37.9)$ & \multirow{2}{*}{$\chi^{2}=5.688$} & 0.128 \\
\hline $6-10$ & $25(22.3)$ & $23(20.5)$ & $48(21.4)$ & & \\
\hline $11-15$ & $33(29.5)$ & $34(30.4)$ & $67(29.9)$ & & \\
\hline $16-18$ & $17(15.2)$ & $7(6.2)$ & $24(10.7)$ & & \\
\hline Total & $112(100.0)$ & $112(100.0)$ & $224(100)$ & & \\
\hline Mean & $8.99 \pm 5.84$ & $9.21 \pm 8.93$ & \multicolumn{1}{|c|}{$t=0.197(p=0.844)$} & \\
\hline Sex & & & & & \\
\hline Male & $68(60.7)$ & $72(64.3)$ & $140(62.5)$ & \multirow{2}{*}{$\chi^{2}=0.641$} & \\
\hline Female & $44(39.3)$ & $40(35.7)$ & $84(37.5)$ & & \\
\hline Total & $112(100.0)$ & $112(100.0)$ & $224(100.0)$ & & \\
\hline
\end{tabular}

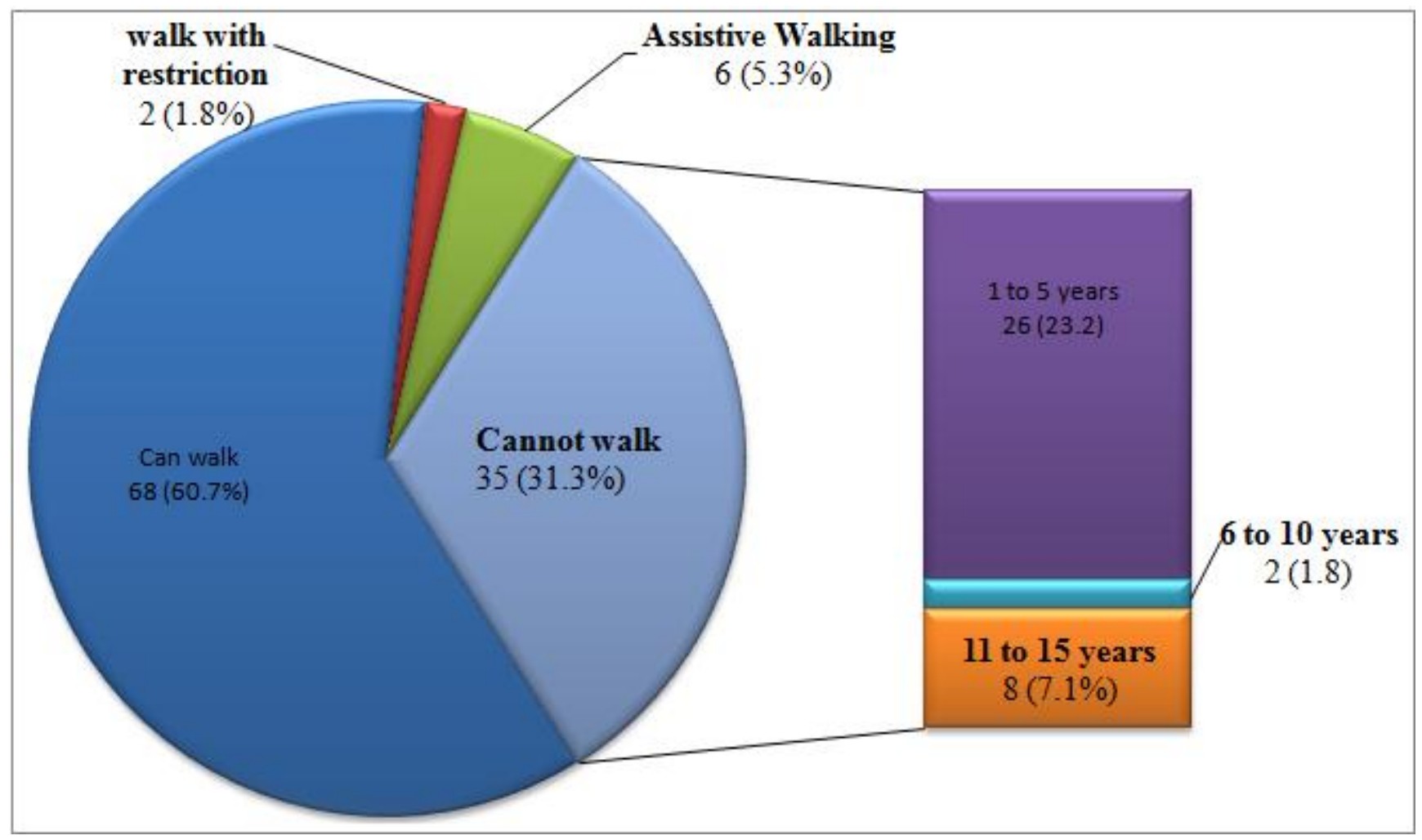

Figure 2: Degree of disability among the cerebral palsy patients

One $(0.9 \%)$ of the patients could not walk, talk nor sit and was in the age range of 1 to 5 years.

Table 2: Age of patient and Degree of disability

\begin{tabular}{|c|c|c|c|c|c|c|}
\hline Age & \multicolumn{5}{|c|}{ Degree of disability } & \\
\cline { 2 - 7 } (years) & $\begin{array}{c}\text { Can } \\
\text { walk } \\
N(\%)\end{array}$ & $\begin{array}{c}\text { Walking } \\
\text { with } \\
\text { restriction } \\
N(\%)\end{array}$ & $\begin{array}{c}\text { Assistive } \\
\text { walking } \\
N(\%)\end{array}$ & $\begin{array}{c}\text { Cannot } \\
\text { walk } \\
N(\%)\end{array}$ & $\begin{array}{c}\text { Cannot } \\
\text { walk, talk } \\
\text { nor sit } \\
N(\%)\end{array}$ & Total \\
\hline $1-5$ & $8(21.6)$ & $1(2.7)$ & $2(5.4)$ & $25(67.6)$ & $1(2.7)$ & $37(33.0)$ \\
\hline $6-10$ & $\begin{array}{c}19 \\
(76.0)\end{array}$ & $1(4.0)$ & $3(12.0)$ & $2(8.0)$ & $0(0.0)$ & $25(22.3)$ \\
\hline $11-15$ & 24 & $0(0.0)$ & $1(3.0)$ & $8(24.2)$ & $0(0.0)$ & $33(29.5)$ \\
\hline $16-18$ & $\begin{array}{c}17 \\
(100.7)\end{array}$ & $0(0.0)$ & $0(0.0)$ & $0(0.0)$ & $0(0.0)$ & $17(15.2)$ \\
\hline Total & $\begin{array}{c}68 \\
(60.7)\end{array}$ & $2(1.8)$ & $6(5.3)$ & $35(31.3)$ & $1(0.9)$ & $112(100.0)$ \\
\hline
\end{tabular}

Table 3: Tympanometric Findings of Cerebral Palsy Patients

\begin{tabular}{|c|c|c|c|}
\hline Variable & \begin{tabular}{|l|} 
Right ear \\
$N=112(\%)$
\end{tabular} & $\begin{array}{c}\text { Left ear } \\
N=112(\%)\end{array}$ & Diagnosis \\
\hline A & $26(23.2)$ & $24(21.4)$ & Normal \\
\hline As & $11(9.8)$ & $11(9.8)$ & $\begin{array}{l}\text { Reduced middle ear } \\
\text { compliance }\end{array}$ \\
\hline Ad & $0(0.0)$ & $0(0.0)$ & \\
\hline B & $11(9.8)$ & $14(12.5)$ & $\begin{array}{l}\text { Otitis Media with } \\
\text { Effusion(OME) }\end{array}$ \\
\hline C1 & $54(48.2)$ & $52(46.4)$ & $\begin{array}{c}\text { Eustachian Tube } \\
\text { Dysfunction, OME }\end{array}$ \\
\hline $\mathrm{C} 2$ & $10(8.9)$ & $11(9.8)$ & $\begin{array}{c}\text { Eustachian Tube } \\
\text { Dysfunction, OME }\end{array}$ \\
\hline Total & $112(100.0)$ & $112(100.0)$ & \\
\hline
\end{tabular}




\section{International Journal of Science and Research (IJSR) \\ ISSN (Online): 2319-7064}

Index Copernicus Value (2013): 6.14 | Impact Factor (2014): 5.611

Type B, Type C1 and Type C2 are indicators of Otitis Media with Effusion (OME) ${ }^{57}$

Type C1 = less severe

Type C2 = more severe

TABLE 4: Tympanometric Findings of the Cases and the Controls, $\mathrm{N}=448$

*Significant

\begin{tabular}{|c|c|c|c|c|c|c|}
\hline Variable & $\begin{array}{c}\text { Case } \\
\mathrm{N}=224(\%)\end{array}$ & $\begin{array}{c}\text { Control } \\
\mathrm{N}=224(\%)\end{array}$ & $\begin{array}{c}\text { Total } \\
\mathrm{N}(\%)\end{array}$ & Test statistic & $\mathrm{df}$ & $\mathrm{p}$ value \\
\hline A & $48(21.4)$ & $134(59.8)$ & $182(40.6)$ & $\chi^{2}=101.000$ & 4 & $<0.001^{*}$ \\
\hline As & $22(9.8)$ & $32(14.3)$ & $54(12.1)$ & & & \\
\hline B & $25(11.2)$ & $26(11.6)$ & $51(11.4)$ & & & \\
\hline C1 & $106(47.3)$ & $27(12.1)$ & $133(29.7)$ & & & \\
\hline C2 & $23(10.3)$ & $5(2.2)$ & $28(6.2)$ & & & \\
\hline Total & $224(100.0)$ & $224(100.0)$ & $448(100.0)$ & & & \\
\hline
\end{tabular}

Type B, Type C1 and Type C2 are indicators of Otitis Media with Effusion (OME) ${ }^{16}$

Table 5: Prevalence of Middle Ear Pathology

\begin{tabular}{|c|c|c|c|}
\hline Variable & $\begin{array}{c}\text { Case } \\
N=224(\%)\end{array}$ & $\begin{array}{c}\text { Control } \\
N=224(\%)\end{array}$ & $\begin{array}{c}\text { Total } \\
N=448(\%)\end{array}$ \\
\hline As, B, C1, C2 & $176(78.6)$ & $90(40.2)$ & $266(59.4)$ \\
\hline OME* $^{*}$ & $154(68.8)$ & $58(25.9)$ & $212(47.3)$ \\
\hline ETD* & $129(57.6)$ & $32(14.3)$ & $161(35.9)$ \\
\hline $\begin{array}{l}\text { Reduced middle } \\
\text { ear compliance }\end{array}$ & $22(9.8)$ & $32(14.3)$ & $54(12.1)$ \\
\hline
\end{tabular}

Multiple interpretation*

Type B, C1 and C2 are indicators of Otitis Media with Effusion (OME) ${ }^{57}$

$\mathrm{C} 1$ and $\mathrm{C} 2$ are indicators of Eustachian tube dysfunction (ETD)

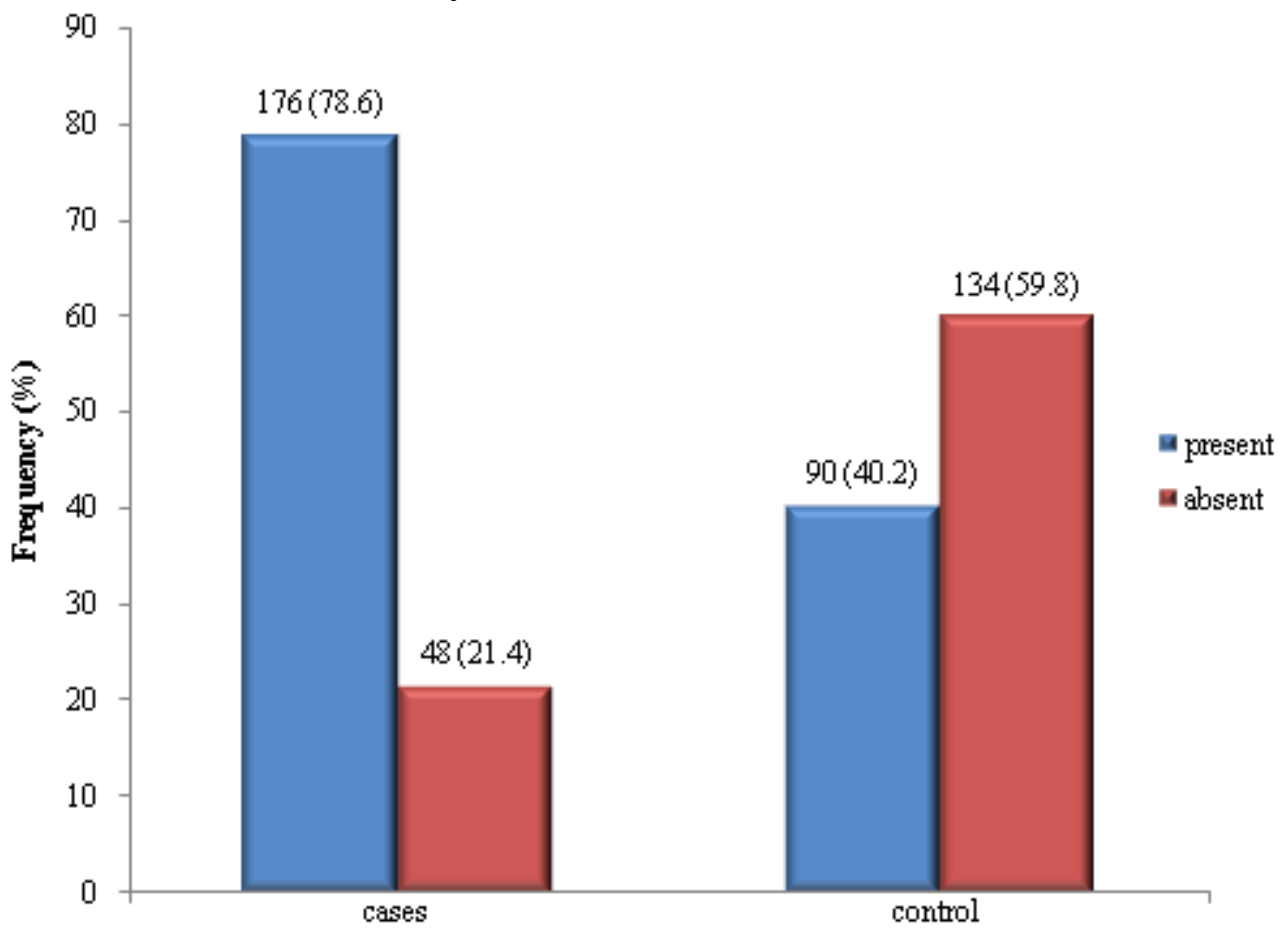

Figure 3: Prevalence of middle Ear Pathology in the Cases and Controls (General Study Population)

\section{Association of Middle Ear Pathology Between Cases and Control}

Table 5.5.1 identifies the presence of middle ear pathology in 176 (66.2\%)ears and 90 (33.8\%) ears of cases and controls respectively, while in relation to absence of middle ear pathology, 48 (26.4\%) and 134 (73.6\%) of cases and controls had no middle ear pathology and this association was statistically significant $(\mathrm{p}<0.001)$

Table 6: Association of Middle Ear Pathology Between Cases and Control

\begin{tabular}{|c|c|c|c|c|c|}
\hline Presence of Middle Ear Pathology & Case N=224(\%) & Control N=224(\%) & Total N=448(\%) & Test Statistic & P value \\
\hline Present & $176(66.2)$ & $90(33.8)$ & $266(59.4)$ & $\chi^{2}=68.289$ & $p<0.001$ \\
\hline Absent & $48(26.4)$ & $134(73.6)$ & $182(40.6)$ & & \\
\hline Total & $224(100.0)$ & $224(100.0)$ & $448(100.0)$ & & \\
\hline
\end{tabular}




\section{International Journal of Science and Research (IJSR) \\ ISSN (Online): 2319-7064 \\ Index Copernicus Value (2013): 6.14 | Impact Factor (2014): 5.611}

Table 7: Prevalence of Middle Ear Pathology Based On Tympanometric Findings in Cerebral Palsy Patients' Right Ear Type $\mathrm{C}$ tracing was more prevalent in all the age groups, in the males and in those who cannot walk.

\begin{tabular}{|c|c|c|c|c|c|c|c|}
\hline \multirow[t]{2}{*}{ Predictors } & \multicolumn{5}{|c|}{ Tympanometry findings } & \multirow[t]{2}{*}{ Test statistic } & \multirow[t]{2}{*}{ p value } \\
\hline & $\begin{array}{l}\text { A } \\
\text { N (\%) }\end{array}$ & $\begin{array}{l}\text { As } \\
\text { N (\%) }\end{array}$ & $\begin{array}{l}\text { B } \\
\text { N (\%) } \\
\end{array}$ & $\begin{array}{l}\mathrm{C} \\
\mathrm{N}(\%) \\
\end{array}$ & $\begin{array}{l}\text { Total } \\
\text { N (\%) } \\
\end{array}$ & & \\
\hline \multicolumn{8}{|l|}{ Age (years) } \\
\hline $1-5$ & $5(13.5)$ & $3(8.1)$ & $4(10.8)$ & 25 (67.6) & $37(100.0)$ & \multirow{5}{*}{$\begin{array}{l}\text { Fisher's exact } \\
=14.194\end{array}$} & 0.213 \\
\hline $6-10$ & $4(16.0)$ & $3(12.0)$ & $2(8.0)$ & $16(64.0)$ & $25(100.0)$ & & \\
\hline $11-15$ & $11(33.3)$ & $2(6.1)$ & $4(12.1)$ & $16(48.5)$ & $33(100.0)$ & & \\
\hline $16-18$ & $6(35.3)$ & $3(17.6)$ & $1(5.9)$ & $7(41.2)$ & $17(100.0)$ & & \\
\hline Total & $26(23.2)$ & $11(9.8)$ & $11(9.8)$ & $64(57.1)$ & $112(100.0)$ & & \\
\hline \multicolumn{8}{|l|}{ Sex } \\
\hline Male & $16(23.5)$ & $8(11.8)$ & $8(11.8)$ & 36 (52.9) & $68(100.0)$ & \multirow{2}{*}{$\begin{array}{l}\text { Fisher's exact } \\
=1.734\end{array}$} & 0.625 \\
\hline $\begin{array}{l}\text { Female } \\
\text { Total }\end{array}$ & $\begin{array}{l}10(22.7) 26 \\
(23.2)\end{array}$ & $\begin{array}{l}3(6.8) \\
11(9.8)\end{array}$ & $\begin{array}{l}3(6.8) \\
11(9.8)\end{array}$ & $\begin{array}{l}28(63.6) \\
64(57.1)\end{array}$ & $\begin{array}{l}44(100.0) \\
112(100.0)\end{array}$ & & \\
\hline \multicolumn{8}{|l|}{ Disability } \\
\hline $\begin{array}{l}\text { Can't talk, walk, sit } \\
\text { nor stand }\end{array}$ & $0(0.0)$ & $0(0.0)$ & $0(0.0)$ & $1(100.0)$ & $1(100.0)$ & \multirow[t]{5}{*}{$\begin{array}{l}\text { Fisher's exact } \\
=13.116\end{array}$} & \multirow[t]{5}{*}{0.307} \\
\hline Can't walk & $7(20.0)$ & $1(2.9)$ & $5(14.3)$ & 22 (62.9) & $35(100.0)$ & & \\
\hline Walk with restriction & $1(50.0)$ & $0(0.0)$ & $0(0.0)$ & $1(50.0)$ & $2(100.0)$ & & \\
\hline Assistive walking & $1(16.7)$ & $1(16.7)$ & $2(33.3)$ & $2(33.3)$ & $6(100.0)$ & & \\
\hline Can walk & $17(25.0)$ & $9(13.2)$ & $4(5.9)$ & $38(55.9)$ & $68(100.0)$ & & \\
\hline
\end{tabular}

Table 8: Prevalence Of Middle Ear Pathology Based On Tympanometric Findings In Cerebral Palsy Patients’ Left Ear Type $\mathrm{C}$ tympanogram was more prevalent in all the age groups, in the males and in those who cannot walk.

\begin{tabular}{|c|c|c|c|c|c|c|c|}
\hline \multirow[t]{2}{*}{ Predictors } & \multicolumn{5}{|c|}{ Tympanometry findings } & \multirow[t]{2}{*}{ Test statistic } & \multirow[t]{2}{*}{$p$ value } \\
\hline & $\begin{array}{c}\text { A } \\
N(\%)\end{array}$ & $\begin{array}{c}\text { As } \\
\mathrm{N}(\%)\end{array}$ & $\begin{array}{c}\text { B } \\
\text { N (\%) }\end{array}$ & $\begin{array}{c}\mathrm{C} \\
\mathrm{N}(\%)\end{array}$ & $\begin{array}{l}\text { Total } \\
\text { N (\%) }\end{array}$ & & \\
\hline \multicolumn{8}{|l|}{ Age (years) } \\
\hline $1-5$ & $6(16.2)$ & $4(10.8)$ & $6(16.2)$ & $21(56.8)$ & $37(100.0)$ & \multirow{5}{*}{$\begin{array}{l}\text { Fisher's exact } \\
=6.127\end{array}$} & 0.924 \\
\hline $6-10$ & $7(28.0)$ & $3(12.0)$ & $2(8.0)$ & $13(52.0)$ & $25(100.0)$ & & \\
\hline $11-15$ & $6(18.2)$ & $2(6.1)$ & $4(12.1)$ & $21(63.6)$ & $33(100.0)$ & & \\
\hline $16-18$ & $5(29.4)$ & $2(11.8)$ & $2(11.8)$ & $8(47.0)$ & $17(100.0)$ & & \\
\hline Total & $24(21.4)$ & $11(9.8)$ & $14(12.5)$ & $63(56.3)$ & $112(100.0)$ & & \\
\hline \multicolumn{8}{|c|}{ Sex } \\
\hline Male & $15(22.1)$ & $5(7.4)$ & $12(17.6)$ & 36 (52.9) & $68(100.0)$ & \multirow[t]{2}{*}{$\chi^{2}=5.111$} & 0.164 \\
\hline $\begin{array}{c}\text { Female } \\
\text { Total } \\
\end{array}$ & $\begin{array}{c}9(20.5) 24 \\
(21.4) \\
\end{array}$ & $\begin{array}{c}6(13.6) 11 \\
(9.8)\end{array}$ & $\begin{array}{c}2(4.5) 14 \\
(12.5)\end{array}$ & $\begin{array}{l}27(61.4) \\
63(56.3) \\
\end{array}$ & $\begin{array}{l}44(100.0) \\
112(100.0) \\
\end{array}$ & & \\
\hline \multicolumn{8}{|c|}{ Disability } \\
\hline $\begin{array}{c}\text { Can't talk, walk, sit } \\
\text { nor stand }\end{array}$ & $0(0.0)$ & $0(0.0)$ & $0(0.0)$ & $1(100.0)$ & $1(100.0)$ & \multirow[t]{5}{*}{$\begin{array}{l}\text { Fisher's exact } \\
=8.464\end{array}$} & \multirow[t]{5}{*}{0.806} \\
\hline Can't walk & $7(20.0)$ & $3(8.6)$ & $7(20.0)$ & $18(51.4)$ & $35(100.0)$ & & \\
\hline Walk with restriction & $0(0.0)$ & $0(0.0)$ & $0(0.0)$ & $2(100.0)$ & $2(100.0)$ & & \\
\hline Assistive walking & $2(33.3)$ & $1(16.7)$ & $1(16.7)$ & $2(33.3)$ & $6(100.0)$ & & \\
\hline $\begin{array}{c}\text { Can walk } \\
\text { Total }\end{array}$ & $\begin{array}{l}15(22.1) \\
24(21.4)\end{array}$ & $\begin{array}{l}7(10.3) \\
11(9.8)\end{array}$ & $\begin{array}{c}6(8.8) \\
14(12.5)\end{array}$ & $\begin{array}{l}40(58.8) \\
63(56.3)\end{array}$ & $\begin{array}{c}68(100.0) \\
112(100.0)\end{array}$ & & \\
\hline
\end{tabular}

\section{TESTING OF HYPOTHESES}

$\mathrm{H}_{01}$ : There is no significant relationship between the prevalence of middle ear pathology and the severity of cerebral palsy (degree of disability).
Data for both hypotheses were derived from table 5.10 below.

$\mathrm{H}_{\mathrm{o} 2}$ : There is no significant relationship between the severity of Eustachian tube dysfunction and the severity of cerebral palsy (degree of disability). 


\section{International Journal of Science and Research (IJSR) \\ ISSN (Online): 2319-7064}

Index Copernicus Value (2013): 6.14 | Impact Factor (2014): 5.611

Table 9: Chi Square of Degree of Disability and Tympanometric Findings

\begin{tabular}{|c|c|c|c|c|c|c|}
\hline Degree of disability & \multicolumn{3}{|c|}{ Tympanometry findings } & Total \\
& $\begin{array}{c}\text { A } \\
\text { N (\%) }\end{array}$ & $\begin{array}{c}\text { As } \\
\text { N (\%) }\end{array}$ & $\begin{array}{c}\text { B } \\
\mathbf{N}(\%)\end{array}$ & $\begin{array}{c}\text { C 1 } \\
\text { N (\%) }\end{array}$ & $\begin{array}{c}\text { C2 } \\
\text { N (\%) }\end{array}$ & N (\%) \\
\hline Cannot walk, talk nor sit & $0(0.0)$ & $0(0.0)$ & $0(0.0)$ & $1(50.0)$ & $1(50.0)$ & $2(100.0)$ \\
\hline Cannot walk & $14(20.0)$ & $4(5.7)$ & $12(17.1)$ & $22(31.4)$ & $18(25.7)$ & $70(100.0)$ \\
\hline Walk with restriction & $1(25.0)$ & $0(0.0)$ & $0(0.0)$ & $2(50.0)$ & $1(25.0)$ & $4(100.0)$ \\
\hline Assistive walking & $3(25.0)$ & $2(16.7)$ & $3(25.0)$ & $4(33.3)$ & $0(0.0)$ & $12(100.0)$ \\
\hline Can walk & $32(23.5)$ & $16(11.8)$ & $10(7.4)$ & $77(56.6)$ & $1(0.7)$ & $136(100.0)$ \\
\hline Total & $50(22.3)$ & $22(9.8)$ & $25(11.2)$ & $106(47.3)$ & $21(9.4)$ & $224(100.0)$ \\
\hline
\end{tabular}

$\chi^{2}=53.558$. The calculated chi square was 53.558 .

\section{COMPUTATION OF THE DEGREE OF FREEDOM (Df).}

$\mathrm{Df}=(\mathrm{R}-1)(\mathrm{C}-1) . \mathrm{R}$ represents the number of rows in the chi-square table above minus one while $\mathrm{C}$ represents the number of columns in the chi-square table minus one.

$(5-1)(5-1)$

$4 \times 4=16$

At 5\% significance level for the degree of freedom the critical value of chi square is 7.962 .

\section{Decision Rule and Interpretation}

Since the calculated chi-square value of 55.558 is more than the chi-square critical value of 7.962, we simply reject the null hypothesis $\left(\mathrm{H}_{\mathrm{o} 1}\right)$ of no significant relationship between prevalence of middle ear pathology and the severity of cerebral palsy (degree of disability).

We also reject the null hypothesis $\left(\mathrm{H}_{02}\right)$ that there is no significant relationship between the severity of Eustachian tube dysfunction and the severity of cerebral palsy (degree of disability).

\section{Discussion}

\section{Patient's Demographic characteristics}

A total of two hundred and twenty four (224) subjects were recruited for the study and 448 ears were assessed. The age range of subjects was from $1-18$ years with mean age as $9.69 \pm 6.53$ years. Majority of the study population in both the cases, 37(33.0\%) subjects, and the control, 48 (42.9) subjects, were $\leq 5$ years of age. Male gender predominated in the cases and the control, 68 (60.7\%) and 72 (64.3\%) respectively. This supports the report that the incidence is higher in males than in females., 17

Prevalence of middle ear pathology based on tympanometric findings

Tympanometry done revealed tracings of Type As, B, C1 and C2 in 176 (78.6\%) ears of the cases compared to 90 $(40.2 \%)$ ears in the controls. This was statistically significant as $\mathrm{p}<0.001$. Normal tympanometric findings were recorded more in the control group, (37.1\%), than in the cases, (29.9\%) which was statistically significant.
Tympanometric evaluation showed Type B tracing in 25 (11.3\%) ears, however a higher value of type B tracing was noted in the control group. This study showed Type C1 in 106 (47.7\%) ears and Type C2 in 21 (9.5\%) ears of the cerebral palsy patients in contrast to $27(12.1 \%)$ and 5 $(2.2 \%)$ respectively in the control group.

Hence, Type C1 is more predominant in this study. Both Type C1 and C2 representing negative pressure in the middle ear are suggestive of Eustachian tube dysfunction. For the purpose of this study, Type B, C1 and C2 tympanograms are indicators of Otitis Media with Effusion. ${ }^{16}$ Thus, these findings are suggestive of Otitis Media with Effusion in these 154 (68.8\%) patients' ears with Type B, C1 and C2 tympanograms. This is in contrast with the study by Hanan El-behairy et al, which recorded Type A tracing, depicting normal middle ear compliance, as being predominant in 18 (60\%) patients and Type B in 2 (6.67\%) patients being the least. ${ }^{10}$ The difference between the results of the studies might probably be due to the difference in sample size (112 and 30) and age range (all pediatric ages and 2months to 8years) of the respective studies. This result is high compared to studies in apparently normal Nigerian children. In a study by Ogisi et al, only $1.2 \%$ type B, and $6.8 \%$ type $C$ tympanograms were recorded in a population of 431 school children aged five to six years. ${ }^{18}$ This difference may be due to the fact that children with cerebral palsy are at higher risk for Otitis Media and Otitis Media with Effusion most likely due to improper hygiene. Lower value $15.9 \%$ was reported in school children by Okolugbo et al using similar diagnostic criteria. ${ }^{16}$ Earlier studies by Ijaduola and Nwawolo recorded prevalence of $18.7 \%$ and $18.2 \%$ respectively. ${ }^{19}$ Higher result of $64 \%$ was recorded in developed country. ${ }^{16}$ It was suggested that the difference was due to Eustachian tube functioning better in Africans though not scientifically supported. ${ }^{20}$ However, these differences may be due to the age group recruited, diagnostic criteria and instruments used.

\section{Pattern of middle ear pathology and Eustachian tube dysfunction}

In this study, Otitis Media with Effusion is the predominant middle ear pathology in 154 (68.8\%) ears followed by Eustachian Tube Dysfunction in 129 (57.6\%) ears. Reduced middle ear compliance was seen in 22 (9.9\%) ears of the patients on Tympanometry. This is in contrast with the study done by Amusa et al, in which Chronic suppurative otitis media (CSOM) was the commonest otological disease recorded in 154 (33.9\%) apparently normal subjects. ${ }^{21}$ Otitis media with effusion (OME) was found in only 24 (5.3\%) of 


\section{International Journal of Science and Research (IJSR) \\ ISSN (Online): 2319-7064 \\ Index Copernicus Value (2013): 6.14 | Impact Factor (2014): 5.611}

their patients. It was also noted in the study that prevalence rate of Otitis Media with Effusion was higher in Europe and America as high as $10 \%$ in pediatric age group. The study recruited similar age group, 6months to 18years.

\section{Severity of eustachian tube Dysfunction}

From this study, Eustachian tube dysfunction varied in severity. A total of 106 ears (42.3\%) of the cerebral palsy patients had Type C1 tympanometric tracing with pressure range of -100 to $-199 \mathrm{mmH}_{2} \mathrm{O}$, compared to 27 (12.1\%) in the control. Type C2 tracing was recorded in 22 ears (9.8\%) with middle ear pressure range of -200 to $-400 \mathrm{mmH}_{2} \mathrm{O}$, in contrast with 5 (2.2\%) in the control group. This contrasts the study by Okolugbo and Ugwu, where Type C1 tracing was noted in 4\% ears and Type C2 in 5\% ears. ${ }^{16}$ Type C tympanogram was noted in $3(5.8 \%)$ subjects by a researcher in Nairobi. ${ }^{22}$ In the study by Ijaduola et al, abnormal tympanograms were reported in 45 (31.3\%) ears. ${ }^{19}$ Cerebral palsy patients may be at higher risk of Eustachian tube orifice occlusion from upper respiratory tract infection due to poor personal hygiene and neglect. A similar criterion for assessing severity of eustachian tube dysfunction in cerebral palsy patients was not available at the period of this study.

\section{Prevalence of middle ear pathology based on tympanometric findings and association with socio- demographic characteristics}

The prevalence of middle ear pathology in this study is $78.6 \%$ in the cerebral palsy patients and $40.2 \%$ in the control group. This was recorded from the abnormal tympanometric findings and is statistically significant as $\mathrm{p}<0.000$. The prevalence of otitis media with effusion and eustachian tube dysfunction is higher in the study group than in the control; (68.8\%: $25.9 \%$ and 57.6\%: $14.3 \%$ respectively) in the general study population.

Table 5.5.1 identifies the presence of middle ear pathology in 176 (66.2\%)ears and 90 (33.8\%) ears of cases and controls respectively, while in relation to absence of middle ear pathology, 48 (26.4\%) and 134 (73.6\%) of cases and controls had no middle ear pathology and this association was statistically significant $(\mathrm{p}<0.001)$

This is in contrast with the study by Ijaduola et al, where the prevalence of Middle ear abnormalities was $20.9 \%$, of which $18.7 \%$ were reported with otitis media with effusion. ${ }^{19}$

In both right and left ears of the study group, Type $\mathrm{C}$ tympanogram was more prevalent in all the age groups, in the males and in those who cannot walk. This finding was not statistically significant when associated with the age, sex and degree of disability, $(p=0.924)$. This agrees with the finding by Tella et al where there is no significant difference between age and physical function. ${ }^{3}$

\section{Testing of Hypotheses}

There is a significant relationship between incidence of middle ear pathology and the severity of cerebral palsy (degree of disability) since the calculated chi-square value of 55.558 is more than the chi-square critical value of 7.962 .
There is also a significant relationship between the severity of Eustachian tube dysfunction and the severity of cerebral palsy (degree of disability).

These findings agree with an earlier study in children with cerebral palsy in which there was significant association between severity of cerebral palsy and health problems. ${ }^{3}$ The health conditions noted included attention deficit in $2.2 \%$, orthopaedic problems in $11.1 \%$, behaviour problems in $13.2 \%$, and cognitive problems in $2.2 \%$. The number of reported medical problems and deformities were higher in children with more severe cerebral palsy. ${ }^{3}$

The awareness of preventable and correctable middle ear pathologies through the health education on the aim and objectives of this study was welcomed by parents and caregivers of these patients.

It is hoped that this study will stimulate better designed prospective studies.

Treatment of Otitis media with effusion will improve the hearing status and speech acquisition in children with cerebral palsy.

\section{Conclusion}

Middle ear pathology is predominant in cerebral palsy patients. Otitis Media with Effusion is the commonest middle ear pathology in cerebral palsy patients. The Eustachian tube dysfunction was mostly Type C1 tracing.

\section{Future Scope}

It is therefore recommended that otorhinolaryngologists should be involved in the management of cerebral palsy patients to improve their quality of life. High index of suspicion and referral for adequate audiological evaluation is needed in the management of these patients. More detailed community based study with objective facilities like Brainstem evoked response Audiometry (BERA), Cortical evoked response Audiometry (CERA) and Speech Audiometry are needed to elucidate completely the middle ear function of Cerebral palsied patients in future studies.

\section{References}

[1] Krigger KW, Cerebral Palsy: An Overview. Am Fam Physician 2006; 73:91-100. Accessed on 19/07/2012

[2] Collins KF, Barker C, Brantley J, et al. The Efficacy of Upper Cervical Chiropractic Care on Children and Adults with Cerebral Palsy: A Preliminary Report. Chiro Pediatrics,1994;1:13-15

[3] Tella BA, Gbiri CA, Osho OA, Ogunrinu AE. HealthRelated Quality of Life of Nigerian Children with Cerebral Palsy. Disability, CBR \& Inclusive Development, 2011; 22: 13- 24

[4] Frank-Briggs AI, Alikor EAD. Pattern of Paediatric Neurological Diseases in Port Harcourt, Nigeria. International Journal of Biomedical Sciences 2011; $7: 145-149$ 


\section{International Journal of Science and Research (IJSR) \\ ISSN (Online): 2319-7064 \\ Index Copernicus Value (2013): 6.14 | Impact Factor (2014): 5.611}

[5] Izuora GI, Iloeje SO. A review of neurological disorders seen at the Paediatric Neurologic Clinic of the University of Nigeria Teaching Hospital, Enugu. Ann Trop Paediatr 1989; 4: 185-190.

[6] Johnson A. Prevalence and characteristics of children with cerebral palsy in Europe. Developmental Medicine \& Child Neurology 2002, 44: 633-640.

[7] The National Institute of Neurological Disorders and Stroke. What Other Medical Disorders Are Associated With Cerebral Palsy? Cerebral Palsy BookletCPParent. Available at www.cpparent.org/cpbooklet.htm. Accessed on 20/08/2012

[8] Onusko E. , Tympanometry. Am Fam Physician. 2004; 70:1713-1720.

[9] Hall 111 JW, Lewis MS. Diagnostic Audiology, Hearing Aids, and Habilitation Options. In: Snow Jr JB, Ballenger JJ, eds. Ballenger's Otorhinolaryngology Head and Neck Surgery.16 ${ }^{\text {th }}$ Ed. Ontario: BC Decker Inc; 2003:139

[10]El-Behairy H, Alyan L, El-Menshawy A, El-Sawah A, Fathy MA, Auditory Impairment in Children with Cerebral Palsy. Australian Journal of Basic and Applied Sciences, 2010 4(12): 6239-6243

[11] Haberfellner H, Welzl-Müller G; Tympanometry in cerebral palsy; Padiatr Padol. 1980;15:121-9.

[12] Cochran WG. Sampling Techniques. John Wiley \& Sons Inc., 1963; 2:134-135.

[13] Araoye MO. Research Methodology with Statistics for Health and Social Sciences. Ilorin Nigeria: Nathadex; 2004:115-154

[14] Reid SM, Modak MB, Berkowitz RG, Reddihough DS. A population-based study and systematic review of hearing loss in children with cerebral palsy. Dev Med Child Neurol. 2011; 53:1038-45

[15] World Medical Association (WMA) declaration of Helsinki- Ethical principles for medical research involving human subjects. Adopted by the $18^{\text {th }}$ WMA General Assembly, Helsinki, Finland, June 1964, amended by the $64^{\text {th }}$ WMA General Assembly, Fortaleza, Brazil, $\quad$ October 2013. http://www.wma.net/en/30publications/10policies/b3. Accessed on 17/12/2014

[16] Okolugbo NE, Ugwu M. Prevalence Of Secretory Otitis Media Amongst Primary School Children in Benin City Nigeria ; Continental J. Medical Research 2009; 3: 12 15

[17] Wikipedia. Cerebral palsy; Epidemiology. free encyclopedia. Accessed 20/10/2013

[18] Ogisi FO, Impedance screening for otitis media with effusion in Nigerian children. J Laryngol Otol. 1988; 102:986-8

[19] Olusanya BO, Okolo AA, Ijaduola GT .The hearing profile of Nigerian school children. International Journal of Pediatric Otorhinolaryngology. 2000 Oct 16; 55:173-9.

[20] Akinlade, O, Nwawolo CC and Okeowo PA: Tympanometric screening for otitis media with effusion (OME) in Nigerian children aged 2-7 years; Nig. Qt. J. Hosp. Med. 1998; 8:44-46

[21] Akinpelu O, Amusa Y: Otological diseases in Nigerian children. The Internet Journal of Otorhinolaryngology. 2007:7:1
[22] Kiama AM. Prevalence of otitis media with effusion in children with Obstructive adenoid disease compared with normal controls at Kenyatta national hospital. Final dissertation for the degree of Master of Medicine in Ear, Nose and Throat Head and Neck Surgery, at the University Of Nairobi.

[23] Fenell Z, Cerebral Palsy \& Ear Infections. eHow health section. Available at www.ehow.com/facts Assessed on 19/07/2012

[24]Elaine G. Children with Cerebral Palsy: A Parents' Guide. Woodbine House,1998;2 Assessed on 20/ 07/ 2012

\section{Author Profile}

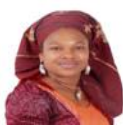

Akpalaba Immaculata Ogechi is a medical doctor, a trained Ear, Nose and Throat specialist (Otorhinolaryngologist) who recently concluded her residency training at the University of Benin Teaching Hospital, UBTH, Benin City, Nigeria.

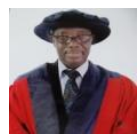

Ogisi Festus O., is a Professor of ear, nose and throat head and neck surgery, a trainer of trainers and the head, department of ear nose and throat, University of Benin Teaching Hospital, UBTH, Benin City, Nigeria. 